\title{
Sexing by External Measurements of Adult Rhinoceros Auklets Breeding on Teuri Island
}

\author{
Yasuaki NIIZUMA ${ }^{1}$, Akinori TAKAHASHI ${ }^{2}$, Maki KUROKI ${ }^{2}$ \\ and Yutaka WATANUKI ${ }^{1}$
}

\author{
1 Laboratory of Applied Zoology, Faculty of Agriculture, Hokkaido \\ University. Sapporo 060-8589, Japan \\ 2 Department of Polar Science, The Graduate University for Advanced \\ Studies, Kaga 1-9-10, Itabashi-ku, Tokyo 173-8515, Japan
}

\begin{abstract}
Sexing without sacrificing or injuring birds is essential for field studies, though it is difficult to sex alcid species with no obvious sexual dimorphism or sex specific display. Rhinoceros Auklets Cerorhinca monocerata breeding on Teuri Island, Hokkaido, Japan had sexual difference in external measurements. A discriminant function was derived from external measurements of 34 male and 39 female breeding auklets. The sexes of the auklets could be separated by using the discriminate function $D=114.22-$ $3.25 \mathrm{BD}-0.64 \mathrm{HL}$, where $\mathrm{BD}$ is bill depth and $\mathrm{HL}$ is head length. $\mathrm{D}$ was negative for males and positive for females. The efficiency of this discriminant function was $91.2 \%$ for males and $100 \%$ for females.
\end{abstract}

Key Words: Cerorhinca monocerata, External measurements, Rhinoceros Auklet, Sexual dimorphism, Teuri Island

Information on sex ratio is one of the important factors of seabird conservation and management (Weimerskirch \& Jouventin 1987). Many seabird species show no obvious sexual dimorphism in plumage or size, even if their body size is different between sexes on average (Fairbairn \& Shine 1993, Croxall 1995). It is also difficult to sex alcids with no obvious sexual dimorphism in plumage or sex specific displays. A large overlap in the external measurements between sexes has been reported in Atlantic Puffins Fratercula arctica (Barrett et al. 1985) and in Cassin's Auklet Ptychoramphus aleuticus (Nelson 1981). Corkhill (1972), however, used discriminant function analysis of bill length and depth to successfully sex Atlantic Puffins.

Rhinoceros Auklets Cerorhinca monocerata breed on offshore islands in the northern Pacific Ocean (Vermeer et al. 1987). The auklets breeding in British Columbia did not show clear sexual dimorphism (Gaston \& Dechesne 1996). However, the auklets breeding on Teuri Island, the other side of the Ocean, had obvious sexual size difference in external measurements. In this paper, we describe a reliable method for determining the sex of the breeding Rhinoceros Auklets.

\section{METHODS}

The study was carried out on Teuri Island $\left(44^{\circ} 25^{\prime} \mathrm{N}, 141^{\circ} 19^{\prime} \mathrm{E}\right)$, Haboro, Hokkaido, in the summers of 1996-1998. Because external traits vary by bird age (Harris 1979), we examined morphological traits of only breeding birds to 
characterize sex difference. A total of 40 birds (19 males and 21 females) were captured by hand in their nest burrows when they incubated eggs or by landing nets when they returned to their nest burrows to feed. They were immediately brought to the laboratory and weighed $( \pm 0.1 \mathrm{~g})$ by electric balance. After they were kept in dark and quiet conditions at least for thirty minutes, they were sacrificed under total anesthesia and with the permission of the Minister of Environment. We also collected 33 carcasses (15 males and 18 females) which were killed by cars on the colony. All carcasses were identified as breeding adults because they had well developed ovaries or testes. Sexes were determined by examination of reproductive organs after dissection. The specimens were stored at $-20 \mathrm{C}$ for later analyses.

The measurements of external traits were carried out after freezing all the specimens. Bill depth (BD; maximum depth of the bill at the front nostril), head length (HL; distance from the tip of the bill to the supraoccipital, Fig. 1), and tarsus length (TL; tarsometatarsus length) were measured to the nearest $0.01 \mathrm{~mm}$ using vernier calipers. Wing length (WL; natural chord) was measured to the nearest $1 \mathrm{~mm}$ using stopped rules. The measurements were carried out several times repeatedly. If the difference of two consecutive measurements were within $0.2 \mathrm{~mm}$, the second one was used in this study. These four measurements were practicable in the field study to minimize human disturbance to the breeding birds. Due to the variability of body mass throughout the breeding season (Jones 1994, Croxall 1995), its sexual difference was not described here.

We used a discriminant function analysis for sex determination with these four measurements. To simplify the function and maintain high discriminant power, we performed an increasing stepwise discriminant analysis.

To examine sexual differences in external traits, Student's t-test was employed for four external measurements. To examine the difference in the degree of sexual

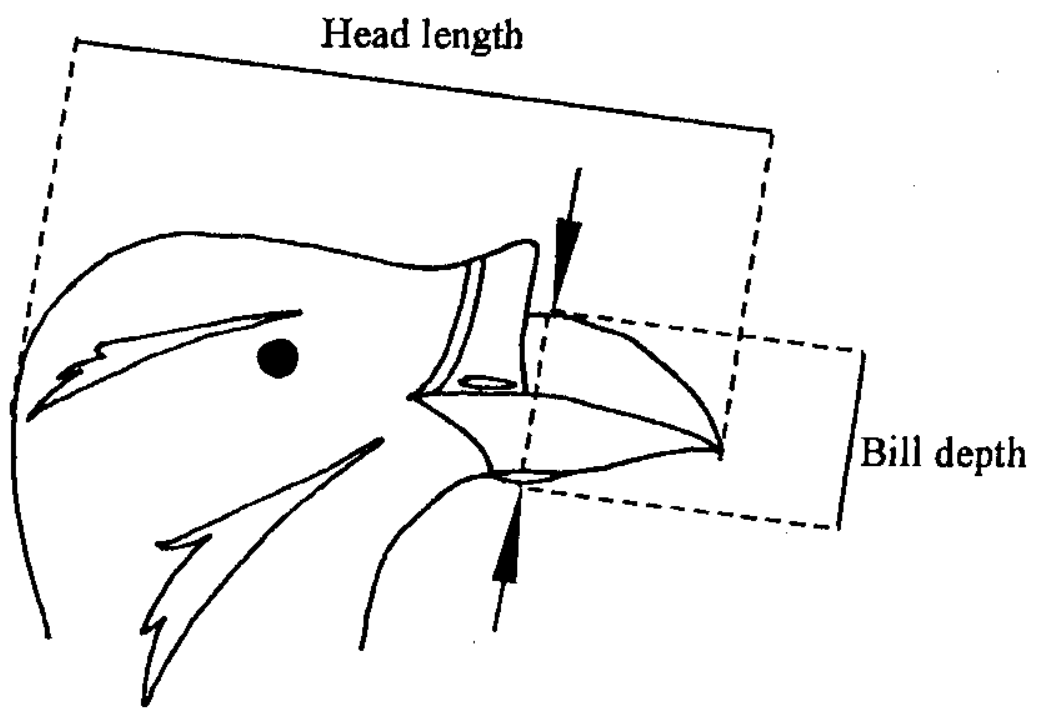

Fig. 1. Bill depth and head length measured to sex Rhinoceros Auklets. 
dimorphism in alcids, $\mathrm{MD}$ index $(\mathrm{MD}=200(\mathrm{Xm}-\mathrm{Xf}) /(\mathrm{Xm}+\mathrm{Xf})(\%))$, where $\mathrm{Xm}$ and $\mathrm{Xf}$ were the mean of the character for males and females, respectively, was calculated; an increasing index indicates greater sexual dimorphism in that character (Agnew \& Kerry 1995).

\section{RESULTS}

Male auklets were significantly larger than females in all external measurements except for WL (Table 1). MD indices of the BD were larger than those of HL, TL and WL. In the stepwise discriminant analysis, BD and HL were selected as predictor variables for the best discriminant function;

$\mathrm{D}=114.22-3.25 \mathrm{BD}-0.64 \mathrm{HL}\left(\mathrm{F}_{2, w}=71.96, p<0.001\right)$.

Table 1. External measurements in Rhinoceros Auklets. Means are given with \pm SD. Range is given in parentheses.

\begin{tabular}{lccccc}
\hline & Males $(\mathrm{n}=34)$ & Female $(\mathrm{n}=39)$ & $t_{n}$ & $\mathrm{p}$-value & MD indices \\
\hline Bill depth(mm) & $18.80 \pm 0.82$ & $16.89 \pm 0.71$ & 10.77 & $<0.001$ & 10.75 \\
& $(17.35-20.79)$ & $(14.90-18.10)$ & & & \\
Head length(mm) & $89.63 \pm 2.23$ & $86.80 \pm 1.81$ & 5.99 & $<0.001$ & 3.21 \\
& $(84.10-95.05)$ & $(82.15-90.38)$ & & & \\
Tarsus length(mm) & $31.43 \pm 1.06$ & $30.68 \pm 1.25$ & 2.74 & $<0.01$ & 2.41 \\
& $(29.70-33.55)$ & $(28.10 \pm 32.80)$ & & & \\
Wing length(cm) & $181 \pm 3.08$ & $179 \pm 5.05$ & 1.62 & n.s. & 0.90 \\
& $(175-186)$ & $(167-188)$ & & & \\
\hline
\end{tabular}

The two variables contributed to the function significantly ( $B D, F_{1,0}=72.14$, $\mathrm{p}<0.001 ; \mathrm{HL}, \mathrm{F}_{1, x}=11.21, \mathrm{p}<0.01$ ). If $\mathrm{D}<0$ the Auklet was classified as male and if $\mathrm{D}>0$ the bird was classified as female. The probability of discrimination on male and female were $91.2 \%$ and $100 \%$, respectively (Fig. 2).

\section{DISCUSSION}

This discriminant function by using the BD and HL was able to sex $95.9 \%$ of the wild adult Rhinoceros Auklets breeding on Teuri Island without sacrificing or injuring them. In the auklets, there was distinct sexual dimorphism as males exhibited larger bill depths than females (see Table 1). Some alcids species exhibit sexual size dimorphism, where males generally have larger bills than females (Corkhill 1972, Nelson 1981, Barrett et al. 1985, Anker-Nilssen et al. 1988, Jones 1993). In previous studies (Corkhill 1972, Nelson 1981, Jones 1993), BL, BD or bill shape have been used to sex alcids. Sexual dimorphism in alcids appears to be developed mainly in their bill size. But WL was not different between sexes. Wings are affected by abrasion throughout the season (Gaston \& Dechesne 1996).

There may be a limit to apply this discriminant function to juveniles and other population of Rhinoceros Auklet. Some external characters continue to develop in 


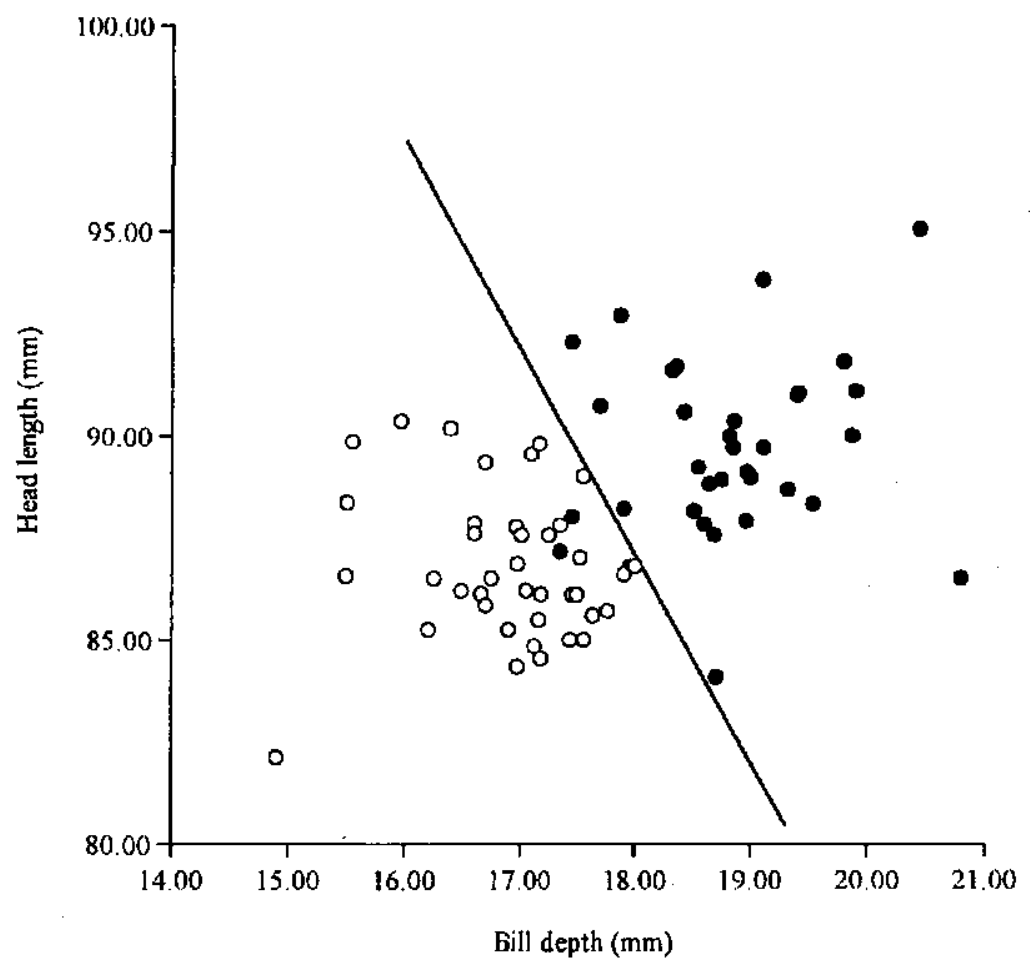

Fig. 2. Relation between bill depth and length of head to the function $0.64 \mathrm{HL}=$ 114.22-3.25 BD, where HL is length of head and BL is bill depth. Open circles show females and closed circles show males.

immature birds until they reach adulthood (Harris 1979), and there are significant regional differences in sizes of seabirds between breeding colonies (Evans et al. 1995, Monterio et al. 1996). Rhinoceros Auklets in British Columbia are slightly smaller than those on Teuri Island and do not show clear sexual size dimorphism (Gaston \& Dechesne 1996). However, their analysis included birds from several different colonies and hence may have been confounded by inter-colony variation (A. J. Gaston, pers. comm.).

To study sexual differences in parental investment and to examine mortality effects on that component of the population (Weimerskirch \& Jouvontin 1987), however, this discriminant function should be useful for sexing breeding Rhinoceros Auklets in field study. Both sexes of monogamous seabirds care for their offspring (Bédard 1985, Warham 1990, Agnew \& Kerry 1995), and different patterns of parental investment between sexes have been reported (Taylor 1994, Bethge et al. 1997, Weimerskirch et al. 1997). Though sexing birds by DNA is not affected by age, regional difference, and statements of injuries (Bradbbury \& Griffiths 1997), it is difficult to apply this technique during field studies, where immediate manipulating sex of parents is necessary. This discriminant function can be also applied to old samples with only morphology data. In conclusion, this discriminant function is a reliable field technique to sex the Rhinoceros Auklets breeding on 
Teuri Island without sacrificing or injuring the birds.

We thank M. Aotsuka for logistical support on the island, H. Fukuda, K. Ishikawa, and Dr. A. Kato for field assistance, and Dr. M. Takagi for statistical advice. We are also very grateful to Dr. A. J. Gaston for helpful comments on an early draft of the manuscript. Anonymous referees helpfully improved our manuscript. M. Chochi kindly corrected our latest draft. Minister of Environment and Education permitted us to work on seabirds on Teuri Island.

\section{LITERATURE CITED}

Agnew, D. J. \& Kerry, K. R., 1995. Sexual dimorphism in penguins. Dann, P., Norman, I., \& Reilly, P., (eds.) The penguins: ecology and management: 298-318. Surrey Beatty and Sons Pty Limited.

Anker-Nilssen, T., Jones, P. H. \& Rostad, O. W., 1988. Age, sex and origins of Auks (Alcidae) killed in the Skagerrak oiling incident of January 1981. Seabird 11: 28-46.

Barrett, R. T., Fieler, R., Anker-Nilssen, T. \& Rikardsen, F., 1985. Measurements and weight changes of Norwegian adult Puffins Fratercula arctica and Kittiwakes Rissa tridactyla during the breeding season. Ringing and Migration 6: 102-112.

Bédard, J., 1985. Evolution and characteristics of the Atlantic Alcidae. Nettleship, D. N. \& Birkhead, T. R. (eds.) The Atlantic Alcidae: the evolution, distribution and biology of the Auks inhabiting the Atlantic ocean and adjacent water areas: 1-51. Academic Press, London, New York.

Bethge, P., Nicols, S., Culik, B. M. \& Wilson, P. R., 1997. Diving behaviour and energetics in breeding Little Penguins Eudyptula minor. Journal of Zoology (London) 242: 483-502.

Bradbury, R. B. \& Griffiths, R., 1997. A rapid method for sexing birds with highly repeated W-chromosome-linked DNA markers. Ibis. 139: 402-403.

Corkhill, P., 1972. Measurements of Puffins as criteria of sex and age. Bird Study 19: 193-201.

Croxall, J. P., 1995. Sexual size dimorphism in seabirds. Oikos 73: 399-403.

Evans, D. R., Hoopes, E. M. \& Griffin, C. R., 1995. Discriminating the sex of Laughing Gulls by linear measurements. Journal of Field Ornithology 64: 472-476.

Fairbairn, J. \& Shine, R., 1993. Patterns of sexual size dimorphism in seabirds of the Southern Hemisphere. Oikos 68: 139-145.

Gaston, A. J. \& Dechsne, S. B. C., 1996. Rhinoceros Auklet Cerorhinca monocerata. The Birds of North America 212: 1-19.

Harris, M. P., 1979. Measurements and weights of British Puffins. Bird Study 26: 179-186.

Jones, I. L., 1993. Sexual differences in bill shape and external measurements of Crested Auklets. Wilson Bulletin 105: 525-529.

Jones, I. L., 1994. Mass changes of Least auklets Aethia pusilla during the breeding season: evidence for programmed loss of mass. Journal of Animal Ecology 63: 71-78.

Monterio, L. R., Ramos, J. A., Furness, R. W. \& Del Nevo, A. J., 1996. Movements, morphology, breeding, molt, diet and feeding of seabirds in the Azores. Colonial Waterbirds 19: 82-97.

Nelson, D. A., 1981. Sexual differences in measurements of Cassin's Auklet. Journal of Field Ornithology 52: 233-234.

Taylor, J. R. E., 1994. Changes in body mass and body reserves of breeding Little Auks (Alle alle L.). Polish Polar Research 15: 147-168. 
Vermeer, K., Sealy, S. G. \& Sanger, G. A., 1987. Feeding ecology of Alcidae in the eastern North Pacific Ocean. Croxall, J. P. (ed.) Seabirds: feeding biology and role in marine ecosystems: 189-227. Cambridge Press, New York.

Warham, J. 1990. The Petrels. Their ecology and breeding systems. Academic Press, London.

Weimerskich, H., Cherel, Y., Cuenot-Chaillet, F. \& Ridoux, V., 1997. Alternative foraging strategies and resource allocation by male and female Wandering Albatross. Ecology 78: 2051-2063.

Weimerskich, H. \& Jouventin, P., 1987. Population dynamics of the Wandering Albatross, Diomedea exulans, of the Crozet Islands : Cause and conservation of the population decline. Oikos 49: 315-322.

(Received 18 January 1999; Accepted 16 August 1999) 
和文抄録 Japanese Summary of Papers in English

\title{
天売島で繁殖するウトウの外部形態による性判別
}

(Sexing by External Measurements of Adult Rhinoceros Auklets Breeding on Teuri Island: 145-150)

\author{
新妻靖章 ${ }^{1}$ 高橋晃周 ${ }^{2} \cdot$ 黒木麻希 ${ }^{2} \cdot$ 綿貫 豊 $^{1}$ \\ 1 北海道大学農学部応用動物学教室, $\overline{\mathbf{T}} 060-8589$ 北海道札幌市北区北 9 西 9 \\ 2 総合大学院大学数物研究科極域科学専攻, $=173-8515$ 東京都板橋区加賀 1-9-10
}

野外調査において対象としている鳥種の性を判別することは重要である. しかし， ウミスズメ類は 明らかな性的二型を外部形態に, またどちらかの性のみによる繁殖ディスプレイを示さないため, 外 見から性を判別することは難しい. 北海道北西部, 日本海に浮かぶ天売島に繁殖するウトゥ, 73羽 (雄34羽雌39羽) の外部形態を計測した後, 内部生殖器によって性を判別した. 嘴高, 頭長とフショ 長において, 雄の方が有意に大きいという性的二型が認められたため, 増加ステップワイズによる判 別分析を試みた。 その結果, 以下の式が得られた.

$\mathrm{D}=114.22-3.25 \mathrm{BD}-0.64 \mathrm{HL}\left(\mathrm{F}_{2,70}=71.96, \mathrm{p}<0.001, \mathrm{BD}\right.$ : 嘴高, HL: 頭長 $)$

判別式が, D< 0 のとき雄, D>0 のとき倠とウトゥは性別され, 雄, 倠の判別率はそれぞれ $91.2 \%$ と100\%であった. しかし, 外部形態は同一種であっても繁殖地間で異なることが知られているので, 天売島以外で繁殖する個体にこの判別式を適用するには注意する必要がある. 外部形態から性を判別 することの利点は, 野外調查において, その場で性を判別し実験操作を可能とするところである.

\section{サシバ Butastur indicus の営巣環境の特性}

(Nest Site Characteristics of the Grey-faced Buzzard Butastur indicus: 151-155)

$$
\text { 小島 幸彦* }
$$

大阪市立大学理学部動物社会学研究室, =558-8585 大阪市住吉区杉本 3-3-138

1977年から1980年にかけて大阪府河内長野市近郊の低山帯でサシバButastur indicus の営巣環境 について調查した. 52本の営巣木が確認され, その多くが山間の小川や水田の近くにあった. 営巣木 の平均標高は $256 \mathrm{~m}(\mathrm{n}=52)$ であった. すべての営巣木は斜面 (平均斜度 $\left.33.3^{\circ}, \mathrm{n}=52\right)$ にあり, 斜 面の位置を下部, 中腹, 上部に区分した場合の営巣木の本数は, それぞれ 23 本, 23 本, 6 本であった 